\title{
GIS-based Geospatial Infrastructure of Water Resource Assessment for Supporting Oil Shale Development in Piceance Basin of Northwestern Colorado
}

\author{
Wei Zhou ${ }^{\text {a, } 1}$, Matthew D. Minnick ${ }^{\mathrm{a}}$, Earl D. Mattson ${ }^{\mathrm{c}}$, Mengistu Geza ${ }^{\mathrm{b}}$, Kyle E. Murray ${ }^{\mathrm{d}}$
}

${ }^{\mathrm{a}, 1}$ Department of Geology and Geological Engineering, Colorado School of Mines, 1516 Illinois Street, Golden, CO 80401, USA, Email: wzhou@mines.edu; Phone: 303-384-2181; Fax: 303273-3859

${ }^{\mathrm{b}}$ Department of Civil and Environmental Engineering, Colorado School of Mines, 1500 Illinois Street, Golden, CO 80401, USA

${ }^{\mathrm{c}}$ Energy Recovery and Sustainability Department, Idaho National Laboratory, P.O. Box 1625, Idaho Falls, ID 83415, USA

${ }^{\mathrm{d}}$ Oklahoma Geological Survey, University of Oklahoma, 100 E. Boyd, Norman, OK 73019, USA

\begin{abstract}
Oil shale deposits of the Green River Formation (GRF) in Northwestern Colorado, Southwestern Wyoming, and Northeastern Utah may become one of the first oil shale deposits to be developed in the U.S. because of their richness, accessibility, and extensive prior characterization. Oil shale is an organic-rich fine-grained sedimentary rock that contains significant amounts of kerogen from which liquid hydrocarbons can be produced. Water is needed to retort or extract oil shale at an approximate rate of three volumes of water for every volume of oil produced. Concerns have been raised over the demand and availability of water to produce oil shale, particularly in semiarid regions where water consumption must be limited and
\end{abstract}


optimized to meet demands from other sectors. The economic benefit of oil shale development in this region may have tradeoffs within the local and regional environment. Due to these potential environmental impacts of oil shale development, water usage issues need to be further studied. A basin-wide baseline for oil shale and water resource data is the foundation of the study. This paper focuses on the design and construction of a centralized geospatial infrastructure for managing a large amount of oil shale and water resource related baseline data, and for setting up the frameworks for analytical and numerical models including but not limited to threedimensional (3D) geologic, energy resource development systems, and surface water models. Such a centralized geospatial infrastructure made it possible to directly generate model inputs from the same database and to indirectly couple the different models through inputs/outputs. Thus ensures consistency of analyses conducted by researchers from different institutions, and help decision makers to balance water budget based on the spatial distribution of the oil shale and water resources, and the spatial variations of geologic, topographic, and hydrogeological Characterization of the basin. This endeavor encountered many technical challenging and hasn't been done in the past for any oil shale basin. The database built during this study remains valuable for any other future studies involving oil shale and water resource management in the Piceance Basin. The methodology applied in the development of the GIS based Geospatial Infrastructure can be readily adapted for other professionals to develop database structure for other similar basins.

\section{Key Words}

Green River Formation; 3D Geologic Model; Retort; Arc Hydro 


\section{Introduction}

Development of oil shale resources in the Western U.S. will require significant quantities of water for oil shale retorting or extracting, reclamation, and associated economic growth. Oil shale development could have a number of impacts on water quality and quantity. The current rate of water consumption is estimated, based on retorting methods from the oil shale industry, to be about a 3:1 water-to-oil ratio (Wood et al., 2008). For oil shale resources with potential to yield almost 0.4 million(M) $\mathrm{m}^{3}(\sim 2.5$ million barrels $(\mathrm{Mbbl})$ or $\sim 322$ acre-feet $(\mathrm{ac}-\mathrm{ft}))$ of oil per day, this equates to $1.2 \mathrm{Mm}^{3}(\sim 7.5 \mathrm{Mbbl}$ or $\sim 967 \mathrm{ac}-\mathrm{ft})$ of water per day for in-situ heating processes, retorting, refining, reclamation, dust control and on-site worker demands.

Collecting regional "baseline" data and compiling them into an integrated database is the foundation of addressing potential water issues due to oil shale development on a regional basis (NETL, 2007). The current methods used in collecting and storing oil shale related data are not sufficient for making these valuable data resources easily available to both the scientific community and policy-makers. Despite different levels of technical knowledge, these data consumers face similar problems including locating, assembling, and integrating heterogeneous domain-specific data into a format that meets their needs. This task could be possible for the technically savvy data consumer, but often only with significant effort that could be better spent on data analysis. The ability to view products based on multiple heterogeneous datasets in a new and novel manner is often the key to enhancing scientific understanding.

A GIS-based centralized water resource geospatial infrastructure was built for data storage, management, manipulation, modeling, and visualization. The geodatabase within the geospatial infrastructure was integrated with 3D geologic, energy resource development systems 
and surface water resource analysis models. The input files of these models were generated directly from the centralized geospatial infrastructure. Thus ensures all models (i.e. 3D geologic, energy resource development systems and surface water models) to look at the same baseline data store in the geodatabase, which ensures consistency of analyses conducted by researchers from different institutions. The models were indirectly coupled though inputs/outputs. For instance, inputs for the geologic and surface water models were directly generated from data stored in the databased, the inputs of the energy resource development systems model were from the output of the geologic model, and the results from the surface water and the energy resource development systems models can facilitate water budget balancing under different oil shale development and climatic scenarios. This endeavor encountered many technical challenging and hasn't been done for any oil shale basin in the past. More specifically, the 3D geologic model was built from borehole, geologic and topographic data stored in the database. The geometric (e.g. thickness of the layers) and hydrogeological properties (e.g. hydraulic conductivity) of the retorting cells for the energy resource development systems model were directly based on the output from the 3D Geologic model, which captures the spatial variation of the resource distribution and hydrogeological characterization throughout the basin. Input files for the surface water model were generated from database semi-automatically by custom-made MatLab scripts. The database built in this study remains valuable for any other future studies involving oil shale and water resource management in the Piceance Basin. The methodology applied in the development of the Geospatial Infrastructure and analytical models can be useful for other professionals to develop similar studies for other similar basins. It was demonstrated a 3D geologic model can be built based on the data collected in the database and the 3D spatial variations of resource distribution and hydrogeological characteristics of the basin can be 
analyzed. It was also demonstrated that water resource analysis and energy resource development systems model models could be built in relatively short time because of the availability of a well-organized database and the 3D geologic model. More detailed information about each model is out of scope of this manuscript and can be found in our final project technical reports to U.S. Department of Energy (DOE) or in our future publications.

\section{Construction of an Integrated Geodatabase}

The Green River Formation (GRF) in the western U.S. has been divided into several distinct geological basins, namely Piceance, Uinta, Green River, and Washakie Basins (Figure 1). The richest and most thoroughly explored deposits occur in the Piceance Basin of Northwestern Colorado. Basin-wide geospatial data, including meteorological, topographic, geologic, and hydrological "baseline", were acquired for the Piceance Basin study area.

The framework of GIS-based models, including the 3D geologic, surface water, and energy resource development systems models, were developed based on the data in the geospatial infrastructure directly or indirectly. Input for these models were usually generated semi-automatically from the data in the geospatial infrastructure by computer programs/scripts. ArcGIS geoprocessing models were developed for analytical purposes, such as volumetric calculation and connections between the geospatial infrastructure and the analytical models. MatLab scripts were developed to process USGS Tops Data into an Mining Visualization System (MVS) input file-format, and to read raw climate data files and populate Arc Hydro format tables. Together, results from the analytical models are capable of supporting decision making on water budget in supporting of oil shale development in the Piceance Basin. Figure 2 shows the high level architecture of the GIS-based water resource geospatial infrastructure for 
this project, including the individual components of the geospatial infrastructure and the connections between the components. The high level architecture provides an overview of an entire system, identifying all its elements at some level of abstraction.

\section{Figure 1.}

Figure 2.

\subsection{Data Acquisition}

Among various oil shale related data, Fisher assay is one of the most frequently used. Fisher assay a standardized laboratory test for determining the oil yield from oil shale to be expected from a conventional shale oil extraction. Major data were collected and compiled including Fischer assays of oil shale drill cores for the Piceance Basin (created by the USGS Oil Shale Assessment Team), National Hydrography Dataset Plus (NHD Plus), 10 meter Digital Elevation Model (DEM) data, geologic maps, subsurface geology, land use dataset, vegetation classification data, stream flow, precipitation, climate, well, ground water level, water use, water rights, and water quality data. Water quality data were collected from the USGS National Water Information System (NWIS) and the U.S. Environmental Protection Agency short for STOrage and RETrieval (STORET) Data Warehouse. Locations for 893 springs were collected from the Colorado Decision Support System (CDSS). Table 1 summarizes various data collected, data sources, and gives brief descriptions of the data (Zhou, et al. 2012).

The 1:100,000 scale geologic quadrangle maps (Hail and Smith, 1994; 1997) of the Piceance Basin were obtained from USGS in DJVU format and were georeferenced into ArcGIS compatible image. Two major products, surface expression of faults and surficial alluvial deposits, were georeferenced and digitized from the USGS 100:000 scale geologic maps for the Piceance Basin and added to the "baseline" geodatabase. 
Additional data were obtained from the Tell Ertl Oil Shale Repository (TEOSR) at the Arthur Lakes Library of Colorado School of Mines after readily available digital resources were exhausted. The TEOSR contains materials related to oil shale and the history of the oil shale industry. Technical materials include journals, government, contractor reports, and unpublished papers of key oil shale players, original research maps, charts, and data compilations.

\section{Table 1.}

\subsection{Data Compilation and Integration}

A database is strictly defined as one or more structured sets of persistent data, managed and stored as a unit and generally associated with software to update and query the data. A geodatabase is a collection of geographic datasets for use by ArcGIS (Date, 2003; ESRI 2004), and can include the spatial locations and shapes of geographic features recorded as points, polylines, polygons, pixels, or grid cells, with attributes and relationships between them (Date, 2003). The geodatabase format in ArcGIS functions similarly to any relational database management system (RDBMS). Data retrieved from various sources are integrated via the geodatabase format into an integrated geodatabase as shown in Figure 2. Basic and advanced GIS operations such as queries, surface creation, multipatch creation, and multicriteria decision analysis can be performed on data stored in the integrated geodatabase.

The database schema was defined using a "data model", which is the representation of a real world phenomenon or system within a database with a conceptually logical framework. When designing a data model the main features of the system must be defined using geographic features, tabular data, and relationships between those features as cardinality or topological relationships. A well designed model or data model allows for efficient analysis of the system behavior. The Arc Hydro Data Model (AHDM) was selected as the database schema for this 
project because it supports the fundamental data types used in this project while being extensible, flexible, and adaptable to our modeling and web-based applications. Arc Hydro has two linked geodatabase schemas, one to support surface water datasets and the other to support groundwater datasets. The Arc Hydro framework supports a tool bar and a geoprocessing toolbox in ArcGIS for data analysis and simple modeling (Maidment, 2002). We elected to build two separate databases at the early stage of the project: an Arc Hydro Surface Water (AHSW) geodatabase, and an Arc Hydro Ground Water (AHGW) geodatabase because it allowed us to better manage the data and avoid duplication of effort. Ultimately, the AHSW and AHGW were broken down into basic components and rebuilt into one geodatabase. An ArcGIS geodatabase schema is summarized in Figure 3 for the implementation of the integrated database. The data schema was customized to support generation of input for the 3D geologic, surface water and energy resource development systems models.

Figure 3.

\subsection{Three-Dimensional (3D) Geologic Model}

Three-Dimensional (3D) geologic modeling, visualization and volume calculation are essential for in-place natural resource evaluation. A fully attributed 3D geologic model of the Piceance Basin was developed for this project to support groundwater modeling, and spatial referencing of the energy resource development system model. The 3D geologic model was based mainly on the USGS Fischer Assay, geologic tops data, and 10-meter resolution DEM.

A Microsoft Access database was obtained from the USGS Oil Shale Assessment Team (Mercier et al., 2009). The database contained tabular data from USGS Fischer assays of oil shale drill cores and rotary cuttings from the Piceance Basin, Colorado. There were 2049 elevation data points for the "tops" of subsurface units acquired from the USGS Fischer Assay 
database (Mercier et al., 2009). The number of data points for elevations of the geological formation tops are itemized in Table 2.

Table 2.

The Mining Visualization Systems (MVS) by C-Tech was chosen for building the 3D geologic model due to the nature of the data and its compatibility with ArcGIS. The geologic framework was interpolated by using a 3D Kriging method adapted from the Geostatistical Software LIBray (GSLIB) within MVS. MatLab scripts were written to process the raw assay and geologic tops data from the USGS geospatial database into MVS input file-format to facilitate advanced visualization and interpolation of the dataset. . Each of the seven attributes in the Microsoft Access Fischer assay database, including amount of shale oil in weight percent, amount of water in weight percent, amount of shale residue in weight percent, amount of "gas plus loss" in weight percent, shale oil in US gallons per short ton of rock, water in US gallons per short ton of rock, and specific gravity of the shale oil, were displayed in 3D as intervals over the borehole trace as shown in Figure 4. A general procedure was developed to transfer the geologic tops database into MVS input file-format as subsets of the available data. Bed pinching was handled in MVS by using a geologic layer hierarchy. This allowed surfaces to cut through each other and subsetted by a top down or bottom up hierarchy then the resulting layer to be subsetted by a specified thickness range resulting in a "pinched bed". The geologic tops database had 103 defined layers consisting of 48 separate beds in the upper and lower GRFs, including the A and B Grooves, the Mahogany, the rich and lean layers of the Lower GRF as well as members of the Wasatch and Mesaverde Formations. The geologic tops, including surface contacts, were interpolated into a subsurface 3D geologic model. The Fischer assay data and any other geologic attributes, such as oil shale resource, water storage, fracture distribution, and hydrogeological parameters, were then interpolated into the geologic framework. 


\section{Figure 4.}

After the first version of the layered 3D geologic model was constructed based on the USGS exploration borehole database related to the Green River Formation (Mercier et al., 2009), inconsistencies related to bed thickness, bed pinching, and structure propagation were identified. These inconsistences were because of data gaps in the borehole log database and resulted in spatial discrepancies when interpolating surfaces. A rigorous process of model quality assurance-quality control (QA-QC) was used to correct these issues in the model. The process involved singling out each interpolated surface and verifying data distribution and resulting structure representation. The top surface for the Mahogany Zone of the GRF colored by elevation reveals the layer is part of a syncline structure (Figure 5). The digitized structure information based on the USGS geologic maps is overlain on the surface interpolation to verify consistency in the layers. This was done for all 19 surfaces in the model. From 50-100 data points were added to each surface to fill out missing sections of the original data and maintain consistency in the structure and average layer thickness in the neighborhood. The Green River oil sale-bearing strata were separated into alternating layers of oil-rich zones (R-zones) and oillean zones (L-zones) following the name convention from Cashion and Donnell (1972) (Self, et al., 2001). From these layers, a full basin scale model was reconstructed at various grid resolutions (Figure 6) and served as the framework of other analytical models, such as the system dynamic model for in-situ oil shale retorting (Zhou et al., 2012). Please note the vertical exaggeration of the model in Figure 6 is 10 times.

\section{Figure 5.}

Figure 6. 


\section{Energy Resource Development Systems Models}

A system dynamic model was constructed to evaluate the water balance for a hypothetical in-situ oil shale conversion project (Mattson et al., 2012) using the Powersim Studio $9^{\mathrm{TM}}$ (version 9.01) software package. Three phases of an in-situ retort were considered: a construction phase that primarily accounts for water needed for drilling and water produced during dewatering, an operation phase that includes the production of water from the retorting process, and a remediation phase that encompasses the water used to remove heat and solutes from the subsurface as well as return the ground surface to its natural state. Depending on the activity being conducted at the simulated retort, the water can be consumed or produced throughout each of these three phases. Consumption takes place for during the drilling process, dust control, returning the ground water to its initial level, and for make-up water losses during remedial flushing of the retort zone. Production of water occurs when dewatering the retort zone, and during kerogen conversion by a chemical pyrolysis reaction. The majority of water consumption occurs during remediation of the in-situ retorting zone (Mattson et al., 2012).

To provide modeling parameters for the hypothetical in-situ oil shale retort, data was extracted from the layered 3D geologic model and was used in the Powersim system dynamic model to constrain the water use model.. The chosen site location was southwest of the Shell Corporation's demonstration sites \#1 and \#3 (Figure 7) and was assumed to have an aerial dimension of $914.4 \mathrm{~m} \times 914.4 \mathrm{~m}$ ( or $3000 \mathrm{ft} \times 3000 \mathrm{ft})$. At this location, subsurface information from well C0213 was accessible in the GIS database. Based on this information it was assumed

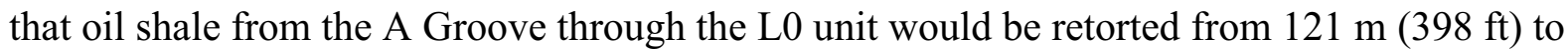
$450 \mathrm{~m}$ (1476 ft), which results in a 360 million cubic meters retorted model. Figure 8 is an example of a typical retorting cell cut out from the geological model. The attributes associated 
with the geologic model were carried over to the cell and make it possible to consider the spatial variations of the basin. Theoretically, the energy resource development systems model can be applied to any retort blocks generated from the 3D geologic model. This would then facilitate better understanding of the temporal and spatial variation of water usage for supporting oil shale development.

\section{Figure 7.}

\section{Figure 8.}

The three sub-models in the energy resource development systems model run independently from one another therefore, water production/consumption of the three phases must be sequentially added. Figure 9 illustrates the net water produced/consumed for the hypothetical retort. Positive slopes represent water production while negative slopes represent water consumption. As seen in Figure 9, although minor water is consumed during drilling and dust control, water is generally produced in the first half of a retort operation due to dewatering of the retort volume and steam production of residual water during heating. The biggest water consumption is during the site restoration activities in the final remediation phase.

, At the end of the hypothetical retort about $79.5 \mathrm{Mm}^{3}$ ( $\sim 500 \mathrm{Mbbl}$ or $\left.\sim 65,000 \mathrm{ac}-\mathrm{ft}\right)$ of water has been consumed (loss) for this hypothetical retort (Figure 9). Due to the richness of the shale beneath this site, the retort is calculated to have produced $54.2 \mathrm{Mm}^{3}(\sim 341 \mathrm{Mbbl}$ or $\sim 44,000$ ac-ft) of oil (Table 3). The ratio of water to oil is 1.47 and is in the range of what the industry has claimed as the expected water use rate. Water usage data generated by the in situ retort system dynamic model can be imported into the GIS database for subsequent analysis surface water modeling to assess the feasibility of conducting such a retort with the available water resources within the basin. 


\section{Figure 9.}

Table 3.

\subsection{Surface Water Modeling}

Watershed Analysis Risk Management Framework (WARMF) model was selected for this study for its capacity of simulating surface water hydrology including stream diversion to assess the impact of water use on stream flow (Figure 10). The input data of the WARMF model was extracted from the integrated geodatabase. Scripts were written in MatLab for formatting input data such as precipitation and stream diversions from the geodatabase in the format required by WARMF model. Data gaps were filled using a data mining technique to bridge the gaps.

\section{Figure 10.}

A preliminary analysis was conducted to determine if there was sufficient surface water available for the proposed hypothetical retort by diverting stream flow from the Parachute and Roan Creek sub-watersheds in the Southern sub-basin and building two reservoirs using Storm Water Management (SWMM) model. SWMM is a dynamic rainfall-runoff simulation model used for single-event to long-term (continuous) simulation of the surface/subsurface hydrology quantity and quality with a capacity for reservoir simulation. The model was used to analyze storage and use of water diverted from Roan and Parachute Creeks.

As a first step to analyze the water availabilty, annual volumes of $19.9 \mathrm{Mm}^{3}(\sim 125 \mathrm{Mbbl}$ or $\sim 16,123 \mathrm{ac}-\mathrm{ft})$ and $19.4 \mathrm{Mm}^{3}(\sim 122 \mathrm{Mbbl}$ or $\sim 15,714 \mathrm{ac}-\mathrm{ft})$ were calculated for Roan and Parachute Creeks, respectively. Ten percent of the simulated flow from Roan and Parachute Creeks was diverted into two separate reservoirs receiving water from each Creek. The simulated 
average annual volume at $10 \%$ diversion rate at reservoirs 1 and 2 were about $2.0 \mathrm{Mm}^{3} / \mathrm{yr}(\sim 12.4$ $\mathrm{Mbbl} / \mathrm{yr}$ or $\sim 1600 \mathrm{ac}-\mathrm{ft} / \mathrm{yr})$ or a combined average diversion volume of $3.9 \mathrm{Mm}^{3}(\sim 24.8 \mathrm{Mbbl}$ or $\sim 3200$ ac-ft). A $10 \%$ diversion rate was used to keep a significant flow within Creeks during the dry periods with most of the diversions occuring during the high flow period. Parachute and Roan Creek are within the proximity of the retorting site and the approach was used to demonstrate the potential for local Creeks to augument water supply for the industry and methodolgy for sizing storage reservoirs if and when such concepts are implemented.

Our finding is that diversion and collection of water in resevoirs from the local creeks would be insufficient water for the previously described hypothetical oil shale retort. The total water demand for the previously described simulated retort is about $80.2 \mathrm{Mm}^{3}(\sim 504 \mathrm{Mbbl}$ or $\sim 65,000 \mathrm{ac}-\mathrm{ft})$ over an 8-year period. The potential volume $\left(31.6 \mathrm{Mm}^{3}\right.$ or $\sim 199 \mathrm{Mbbl}$ or $\sim 25,600$ ac-ft) captured by Roan and Parachute Creeks over this period of time is less than half the required water if all available water is diverted. Thus, based on this analysis most of the water requirement should come from either the Colorado or White River or from a groundwater source and the creeks within the retorting area in the south can only provide supplemetal water.

\subsection{Discussion and Conclusions}

A water resource geospatial infrastructure for supporting oil shale development has been developed in this project which creates a repository for storing large volumes of data, such as oil shale, geological, hydrogeological, topological, water resource and climatic data. The geospatial infrastructure includes data frame/data model, geodatabase, database-related customized computer programs/scripts, and tools/models, and analytical models, including 3D geologic, energy resource development systems, and water resource models. The results of this research 
can help decision makers to manage water resource and balance water budge under various oil shale development scenarios.

The geodatabase within the geospatial infrastructure is the foundation of the research and allows for collaborative regional/basin assessments for future oil shale development based on the same "baseline". The 3D geological model provides better understanding through data interpolation and visualization techniques of the Piceance Basin structure spatial distribution of the oil shale resources. The surface water model quantifies the water shortage and better understanding the spatial distribution of the available water resources. The energy resource development model reveals the phase shift of water usage and the oil shale production, which will facilitate better planning for oil shale development.

The key findings of this research include: (1) Spatial and temporal water distribution is highly variable in the Piceance Basin; (2) Surface water is limited within Piceance Basin, with largest discharge being Roan and Parachute Creek at $19.9 \mathrm{Mm}^{3} /$ year $(\sim 16,123 \mathrm{acre}-\mathrm{ft} / \mathrm{yr})$ and 19.4 $\mathrm{Mm}^{3} /$ year ( 15,714 acre-ft/yr), respectively; (3) Diversion and collection of water in reservoirs from the local creeks are insufficient for aforementioned hypothetical oil shale retort or extraction; and (4) The energy resource development systems modeling reveals that water consumption is not linearly related to oil shale production. Site construction and oil shale production have an overall water production and site remediation is the major water consumption phase.

We have also identified data issues in this study, which include but are not limited to data gaps or lacking of data in Fischer assay, fracture network, porosity and permeability, potientmetric surface data for upper and lower Greenriver Aquifers, comprehensive water quality (both surface and groundwater), and stream flow gains and loss with groundwater. There are also 
limitations in this study, which include but are not limited to water resources analysis considers only the volume of water available, but not any of the impacts associated with how it is obtained. Fracture network was not considered in the energy resource development systems model.

\subsection{Acknowledgements}

This research was funded by U.S. Department of Energy (Award \# DE-NT0006554). We thank USGS Energy Resource Program staff and scientists for making countless datasets publicly available. We also acknowledge the Colorado Decision Support System (Colorado Division of Water Resources), and the Tell Ertl Oil Shale Repository (TEOSR) at the Arthur Lakes Library of Colorado School of Mines as important sources of data. Several anonymous peer-reviewers are also acknowledged for providing input to improve this paper.

\subsection{References}

Cashion, W.B., and Donnell, J.R., 1972, Chart showing correlation of selected key units in the organic-rich sequence of the Green River Formation, Piceance Creek Basin, Colorado, and Uinta Basin, Utah: U.S. Geological Survey Oil and Gas Investigations Chart OC-65.

Date, C. J., 2003. An Introduction to Database Systems, $8^{\text {th }}$ edition, Addison Wesley 1024pp. ESRI (Environmental Systems Research Institute, Inc.), 2004. Building A Geodatabase, ESRI digital book, ESRI Press, Redlands, California, 382pp.

Hail, W. J., and M. C. Smith, 1994. Geologic map of the northern part of the Piceance Creek Basin, northwestern Colorado, U.S. Geological Survey Miscellaneous Investigations Series Map I-2400.

Hail, W. J., and M. C. Smith, 1997. Geologic map of the southern part of the Piceance Creek Basin, northwestern Colorado, U.S. Geological Survey Miscellaneous Geologic Investigations Map I-2529. 
Maidment D. R. (Ed), 2002. Arc Hydro - GIS for Water Resources, ERSI Press, Redlands, California, $1^{\text {st }}$ Edition, 208pp.

Mattson, E. D., L. Hull, and K. Cafferty, 2012. Water Usage for In-Situ Oil Shale Retoring - A System Dynamics Model, 2012, Idado National Laborotary Report, Report No. INL/EXT$1227365,51 \mathrm{pp}$.

Mercier, T. J., M. E. Brownfield, R. C. Johnson, and J. G. Self, 2009. Fischer assays of oil shale drill cores and rotary cuttings from the Piceance Basin, Colorado - 2009 update, edited, U.S. Geological Survey Open-File Report 98-483 Version 2, 16pp.

NETL (National Energy Technology Laboratory, U.S. Department of Energy), 2007. 2007 Oil Shale Environmental Issues and Needs Workshop Report, 61pp.

Self, J.G., Johnson, R.C., Brownfield, M.E., and Mercier, T.J., 2010, Stratigraphic cross sections of the Eocene Green River Formation in the Piceance Basin, northwestern Colorado: U.S. Geological Survey Digital Data Series DDS-69-Y, chapters. 5, 7 p.

Zhou, W., M. Minnick, M. Geza, K. Murray, and E. Mattson, 2012. GIS- and Web-based Water Resources Geospatial Infrastructure for Oil Shale Development, the Final Project Report to United States Department of Energy, National Energy Technology Laboratory, December 29, 2012, Report No. DOE/NT0006554-1, 143pp. 


\section{List of figure captions}

Figure 1. Locations of four Green River Formation basins in Colorado, Utah, and Wyoming

Figure 2. High level architecture of the GIS-based water resource geospatial infrastructure shows the workflow ranging from data acquisition, geodatabase design, building Desktop GIS, building server GIS, and connections of the geodatabase and the GIS-based models.

Figure 3. The ArcCatalog tree of the integrated database partially shows the structure of the database, such as file geodatabase tables, relationship classes, feature datasets, and rasters.

Figure 4. Visualization of the oil content (in Gallons per Ton) from the Fischer assay measurements in MVS with the top surface defined by a 10 meter DEM.

Figure 5. Image of the top of Mahogany surface in the Green River Formation colored by elevation to reveal the layer structure, which is then verified against USGS structural interpretations.

Figure 6. Vertically exaggerated (10 times) output from the basin wide 3D geologic model after QA-QC.

Figure 7. Location for the simulated retort area.

Figure 9. Cumulative water extracted versus time from hypothetical simulation.

Figure 10. Watershed delineation and subdivisions for Piceance Basin, Colorado.

\section{List of table captions}

Table 1. Summary of data acquisition*

Table 2. Summary of contents of Fischer assay database by geologic units

Table 3. Subsurface information from the integrated GIS database 
Table 1

\begin{tabular}{|c|c|c|c|}
\hline NAME & SOURCE & DESCRIPTION & $\begin{array}{l}\text { GEODATABASE } \\
\text { FEATURE }\end{array}$ \\
\hline $\begin{array}{l}\text { watersheds } \\
\text { catchments }\end{array}$ & NHDPlus & $\begin{array}{l}\text { watershed and catchments polygons at } \\
\text { various scales }\end{array}$ & $\begin{array}{l}\text { polygon feature } \\
\text { classes }\end{array}$ \\
\hline elevation & NED & $\begin{array}{l}\text { Digital Elevation Models with } 10 \mathrm{~m} \\
\text { resolution }\end{array}$ & GeoRasters \\
\hline $\begin{array}{l}\text { stream } \\
\text { networks }\end{array}$ & NHDPlus & $\begin{array}{l}\text { stream line data networked in a reach and } \\
\text { nodal system }\end{array}$ & $\begin{array}{l}\text { polyline feature } \\
\text { class }\end{array}$ \\
\hline $\begin{array}{l}\text { flow } \\
\text { accumulation }\end{array}$ & NHDPlus & $\begin{array}{l}\text { flow network and direction data linked to } \\
\text { the stream network }\end{array}$ & related table \\
\hline flow gages & $\begin{array}{l}\text { CDSS, } \\
\text { NWIS }\end{array}$ & USGS flow gage point locations & point feature class \\
\hline flow data & NWIS & time series stream flow data & time series table \\
\hline $\begin{array}{l}\text { climate } \\
\text { stations }\end{array}$ & $\begin{array}{l}\text { NOAA, } \\
\text { CDSS }\end{array}$ & locations for climate monitoring stations & point feature class \\
\hline climate data & NOAA & $\begin{array}{l}\text { time series for up to } 55 \text { climate/weather } \\
\text { parameters }\end{array}$ & time series table \\
\hline $\begin{array}{l}\text { surface water } \\
\text { quality }\end{array}$ & $\begin{array}{l}\text { NWIS, } \\
\text { EPA }\end{array}$ & $\begin{array}{l}\text { water quality data linked to monitoring } \\
\text { locations }\end{array}$ & point feature class \\
\hline $\begin{array}{l}\text { aerial } \\
\text { imagery }\end{array}$ & $\begin{array}{l}\text { USGS, } \\
\text { NAIP }\end{array}$ & aerial imagery at varying resolutions & raster catalog \\
\hline $\begin{array}{l}\text { geologic } \\
\text { maps }\end{array}$ & $\begin{array}{l}\text { CGS, } \\
\text { USGS }\end{array}$ & georeferenced geologic maps & $\begin{array}{l}\text { GeoRasters and } \\
\text { GeoArea feature } \\
\text { class }\end{array}$ \\
\hline $\begin{array}{l}\text { subsurface } \\
\text { geology }\end{array}$ & USGS & $\begin{array}{l}\text { borehole data from exploration wells } \\
\text { including geophysical, formation tops, } \\
\text { oil shale richness data }\end{array}$ & $\begin{array}{l}\text { GeoVolume } \\
\text { multipatch feature } \\
\text { class }\end{array}$ \\
\hline wells & NWIS & water well production and source data & point feature class \\
\hline water level & NWIS & water level measurements for wells & time series table \\
\hline $\begin{array}{l}\text { ground water } \\
\text { quality }\end{array}$ & NWIS & water quality data associated with wells & time series tables \\
\hline $\begin{array}{l}\text { Hydro- } \\
\text { geologic data }\end{array}$ & $\begin{array}{l}\text { CGS, } \\
\text { USGS }\end{array}$ & $\begin{array}{l}\text { hydrologic parameter data derived from } \\
\text { cores and pumping tests }\end{array}$ & tables \\
\hline land cover & NLCD & vegetation and barren land data & raster feature set \\
\hline land use & BLM & land use and ownership data & $\begin{array}{l}\text { custom polygon } \\
\text { feature class }\end{array}$ \\
\hline base maps & $\begin{array}{l}\text { USGS, } \\
\text { ESRI }\end{array}$ & $\begin{array}{l}\text { general maps including roads, towns, site } \\
\text { names, and USGS topographic maps }\end{array}$ & ESRI online map \\
\hline springs & CDSS & locations of springs & $\begin{array}{l}\text { HydroPoint feature } \\
\text { class }\end{array}$ \\
\hline spring flow & CDSS & $\begin{array}{l}\text { time series data of water flow from } \\
\text { springs }\end{array}$ & time series tables \\
\hline
\end{tabular}




\begin{tabular}{llll}
\hline diversions & CDSS & $\begin{array}{l}\text { water discharge and withdraw from } \\
\text { irrigation ditches, stock ponds, } \\
\text { reservoirs, stream pumping Locations } \\
\text { and wells }\end{array}$ & $\begin{array}{l}\text { point feature } \\
\text { classes }\end{array}$ \\
\hline $\begin{array}{l}\text { diversion } \\
\text { flow }\end{array}$ & CDSS & water flow and usage & time series tables \\
\hline pumping tests & CSM & $\begin{array}{l}\text { Testes conducted by various institutions } \\
\text { throughout the years compiled from non- } \\
\text { digital documents }\end{array}$ & point feature class \\
\hline $\begin{array}{l}\text { surficial } \\
\text { geological } \\
\text { structure }\end{array}$ & digitized & $\begin{array}{l}\text { surface expression of geological } \\
\text { structures digitized from USGS geologic } \\
\text { map }\end{array}$ & $\begin{array}{l}\text { polyline feature } \\
\text { class }\end{array}$ \\
\hline $\begin{array}{l}\text { surficial } \\
\text { alluvial } \\
\text { deposits }\end{array}$ & digitized & $\begin{array}{l}\text { surficial alluvial deposits that make up } \\
\text { the stream valleys digitized from USGS } \\
\text { geologic map }\end{array}$ & $\begin{array}{l}\text { polygon feature } \\
\text { class }\end{array}$ \\
\hline
\end{tabular}

*NHDPlus - National Hydrologic Dataset Plus; NED - National Elevation Dataset; CDSS - Colorado's Decision Support System; NWIS - National Weather Information System; USGS - United States Geological Survey; NOAA - National Oceanic and Atmospheric Administration; EPA - Environmental Protection Agency; NAIP - National Agriculture Imagery Program; ESRI - Environmental Systems Research Institute; CGS - Colorado Geological Survey; NLCD - National Land Cover Dataset; BLM Bureau of Land Management; CSM TEOSR - Colorado School of Mines Tell Ertl Oil Shale Repository 
Table 2.

\begin{tabular}{cc}
\hline Subsurface unit & Number of Top Elevations \\
\hline A-groove & 191 \\
\hline Mahogany bed & 243 \\
\hline B-groove & 211 \\
\hline R-6 zone & 177 \\
\hline L-5 zone & 129 \\
\hline R-5 zone & 126 \\
\hline L-4 zone & 119 \\
\hline R-4 zone & 119 \\
\hline L-3 zone & 118 \\
\hline R-3 zone & 115 \\
\hline L-2 zone & 109 \\
\hline R-2 zone & 107 \\
\hline L-1 zone & 102 \\
\hline R-1 zone & 79 \\
\hline L-0 zone & 56 \\
\hline R-0 zone & 48 \\
\hline
\end{tabular}


Table 3

\begin{tabular}{lrrrrrrr}
\hline $\begin{array}{l}\text { Layer } \\
\text { Name }\end{array}$ & $\begin{array}{c}\text { Average } \\
\text { Thicknes } \\
\mathrm{s}(\mathrm{m})\end{array}$ & $\begin{array}{r}\text { Volume } \\
\left(10^{6} \mathrm{~m}^{3}\right)\end{array}$ & $\begin{array}{c}\text { Porosit } \\
\mathrm{y}(\%)\end{array}$ & $\begin{array}{c}\text { Hydraulic } \\
\text { Conductivity } \\
(\mathrm{cm} / \text { day })\end{array}$ & $\begin{array}{c}\text { Average } \\
\text { Oil (GPT) } \\
\text { Based on } \\
\text { C0213 }\end{array}$ & $\begin{array}{c}\text { Water in } \\
\text { Matrix } \\
(\mathrm{GPT})\end{array}$ & \multicolumn{1}{c}{$\begin{array}{c}\text { Oil volume } \\
\text { (gal) }\end{array}$} \\
\hline $\begin{array}{l}\text { Upper } \\
\text { GRF }\end{array}$ & 121.3 & 101.4 & 10 & 36.6 & $\mathrm{~N} / \mathrm{A}$ & $\mathrm{N} / \mathrm{A}$ & \\
\hline A Groove & 3.7 & 3.2 & 10 & 36.6 & 6.2 & 1.3 & $44,104,320$ \\
\hline Mahogany & 36.3 & 30.6 & 1 & 0.3 & 25.4 & 3.8 & $1,711,756,800$ \\
\hline B Groove & 7.3 & 6.1 & 10 & 36.6 & 5.7 & 1.0 & $76,826,880$ \\
\hline R6 & 36.0 & 30.3 & 1 & 0.3 & 19.9 & 3.4 & $1,328,683,200$ \\
\hline L5 & 24.7 & 20.9 & 10 & 18.3 & 11.7 & 5.4 & $538,068,960$ \\
\hline R5 & 55.2 & 46.4 & 15 & 12.2 & 28.9 & 9.0 & $2,957,510,400$ \\
\hline L4 & 20.1 & 16.8 & 20 & 61.0 & 21.8 & 7.1 & $806,669,760$ \\
\hline R4 & 21.3 & 18.0 & 15 & 12.2 & 33.3 & 4.8 & $1,321,557,120$ \\
\hline L3 & 11.3 & 10.8 & 8 & 12.2 & 11.3 & 4.5 & $27,006,0960$ \\
\hline R3 & 22.9 & 19.2 & 1 & 0.3 & 24.5 & 4.2 & $103,958,4000$ \\
\hline L2 & 7.9 & 7.1 & 5 & 6.1 & 15.3 & 4.8 & $237,725,280$ \\
\hline R2 & 24.4 & 20.4 & 1 & 0.3 & 26.9 & 6.4 & $1,211,920,320$ \\
\hline L1 & 9.4 & 8.0 & 3 & 6.1 & 5.4 & 10.5 & $9,4685,760$ \\
\hline R1 & 33.8 & 28.3 & 0.5 & 0.3 & 19.4 & 9.1 & $1,210,560,000$ \\
\hline L0 & 14.3 & 12.0 & 3 & 6.1 & 5.5 & 7.8 & $145,860,000$ \\
\hline R0 & 43.9 & 36.8 & 0.5 & 0.3 & N/A & N/A & \\
\hline & & & & & & & \\
\hline
\end{tabular}




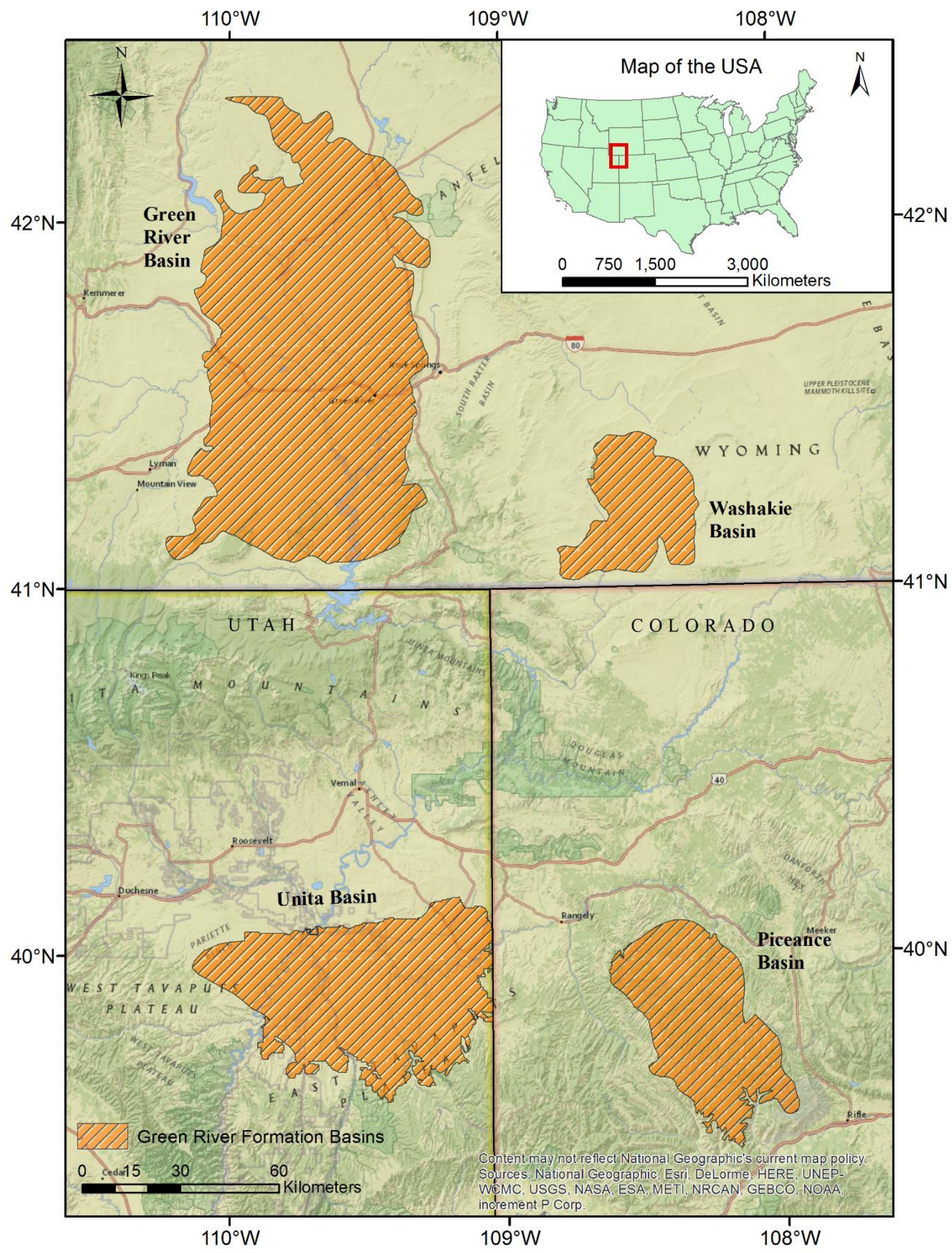




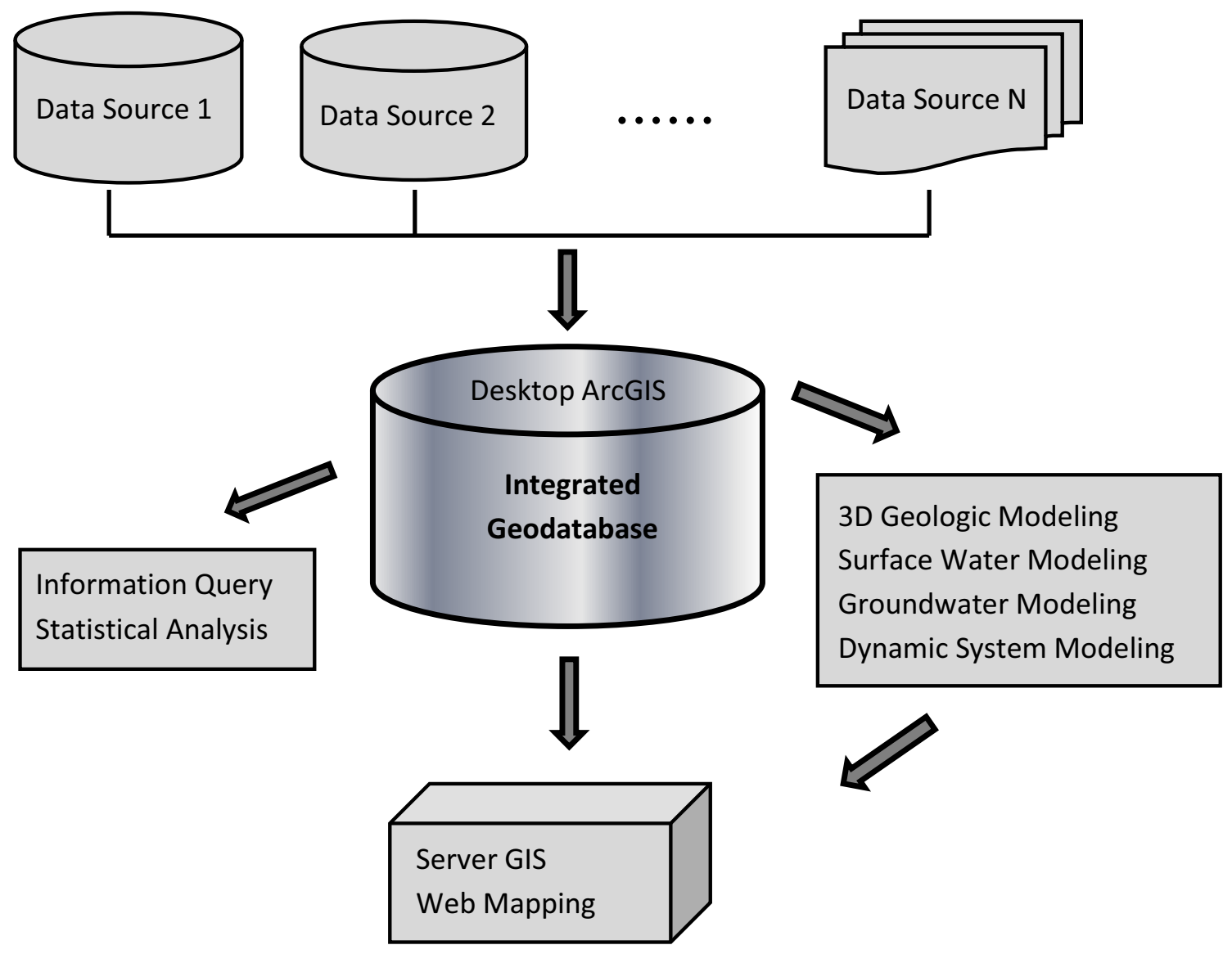




\begin{tabular}{|c|c|c|c|}
\hline Catalog Tree & $x$ & & \\
\hline 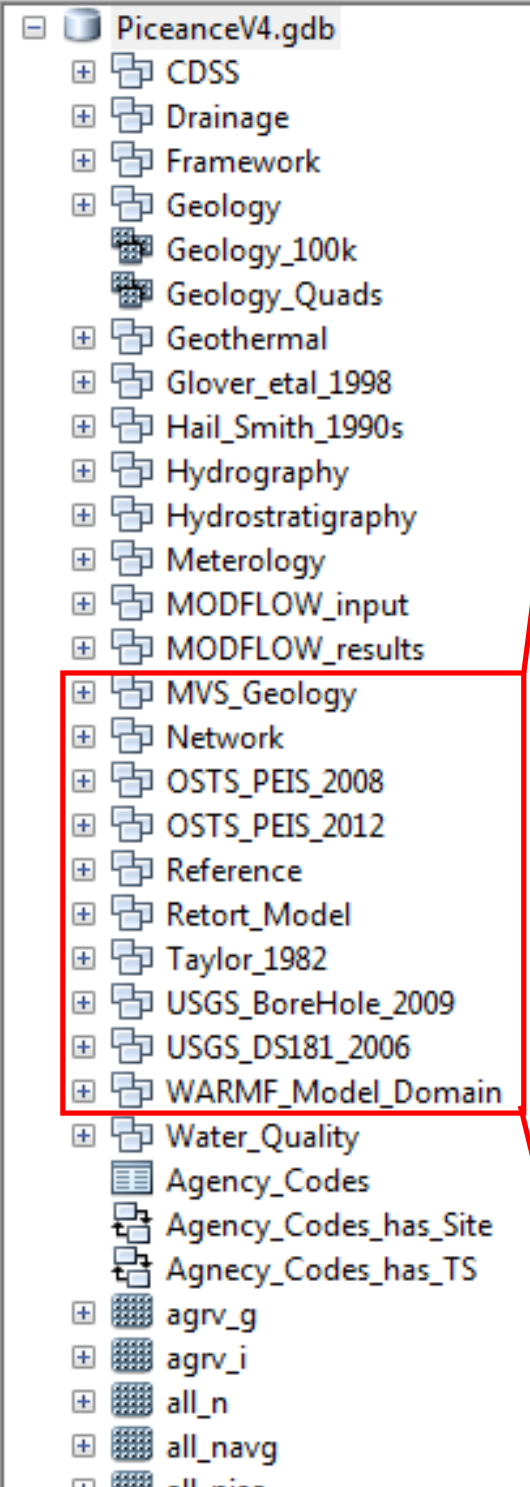 & 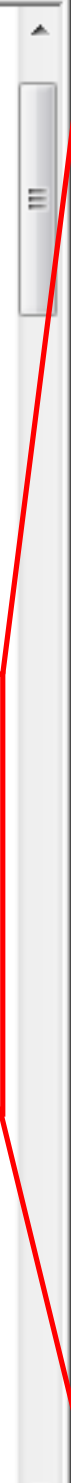 & 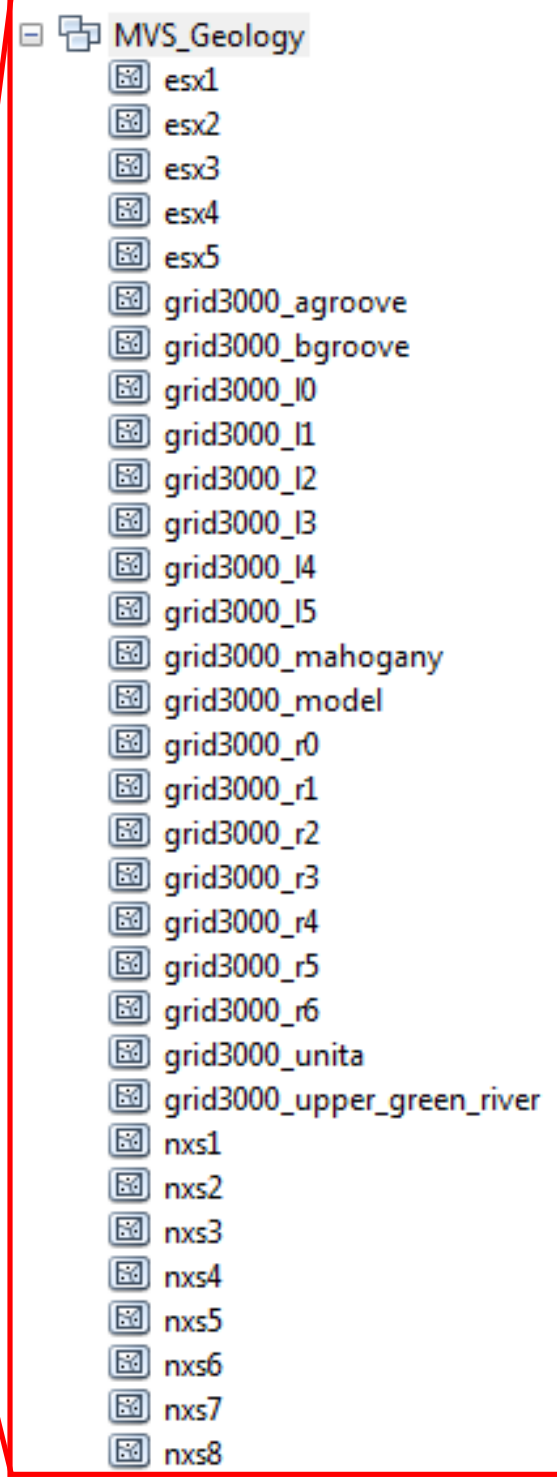 & 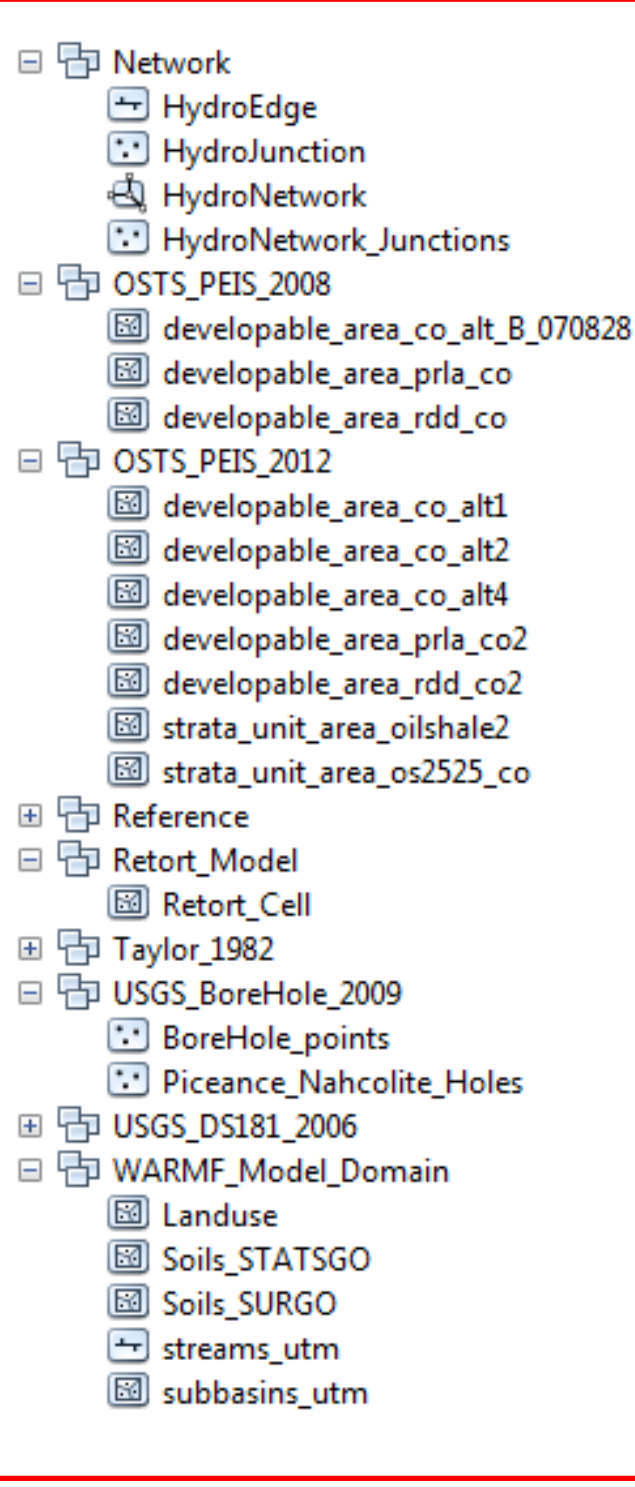 \\
\hline $\begin{array}{c} \pm \text { all_niso } \\
\text { III } \\
\end{array}$ & & & \\
\hline
\end{tabular}




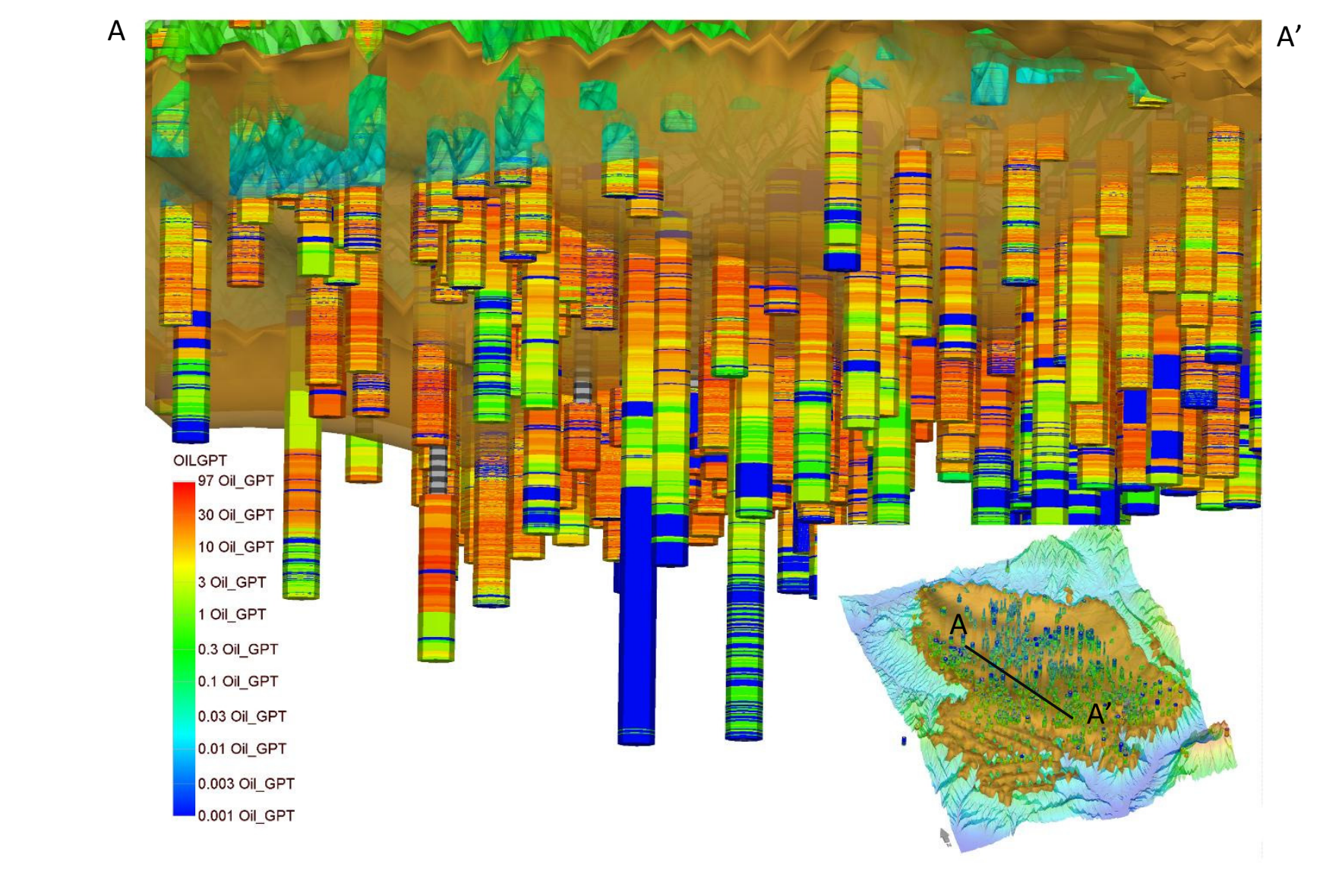

Figure(s)

.

(s)
(

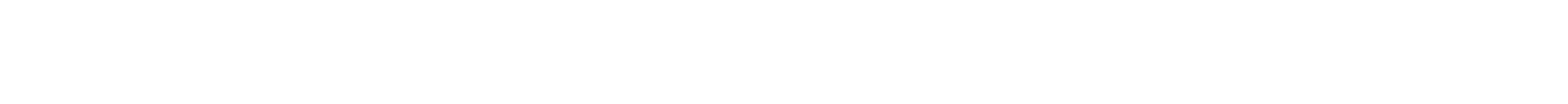

-
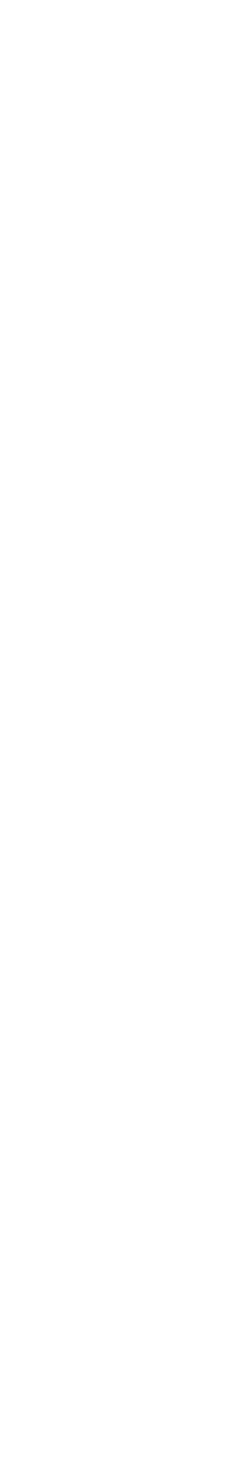
:

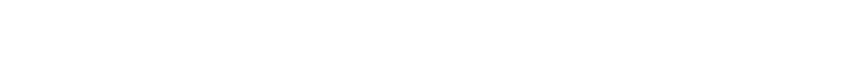




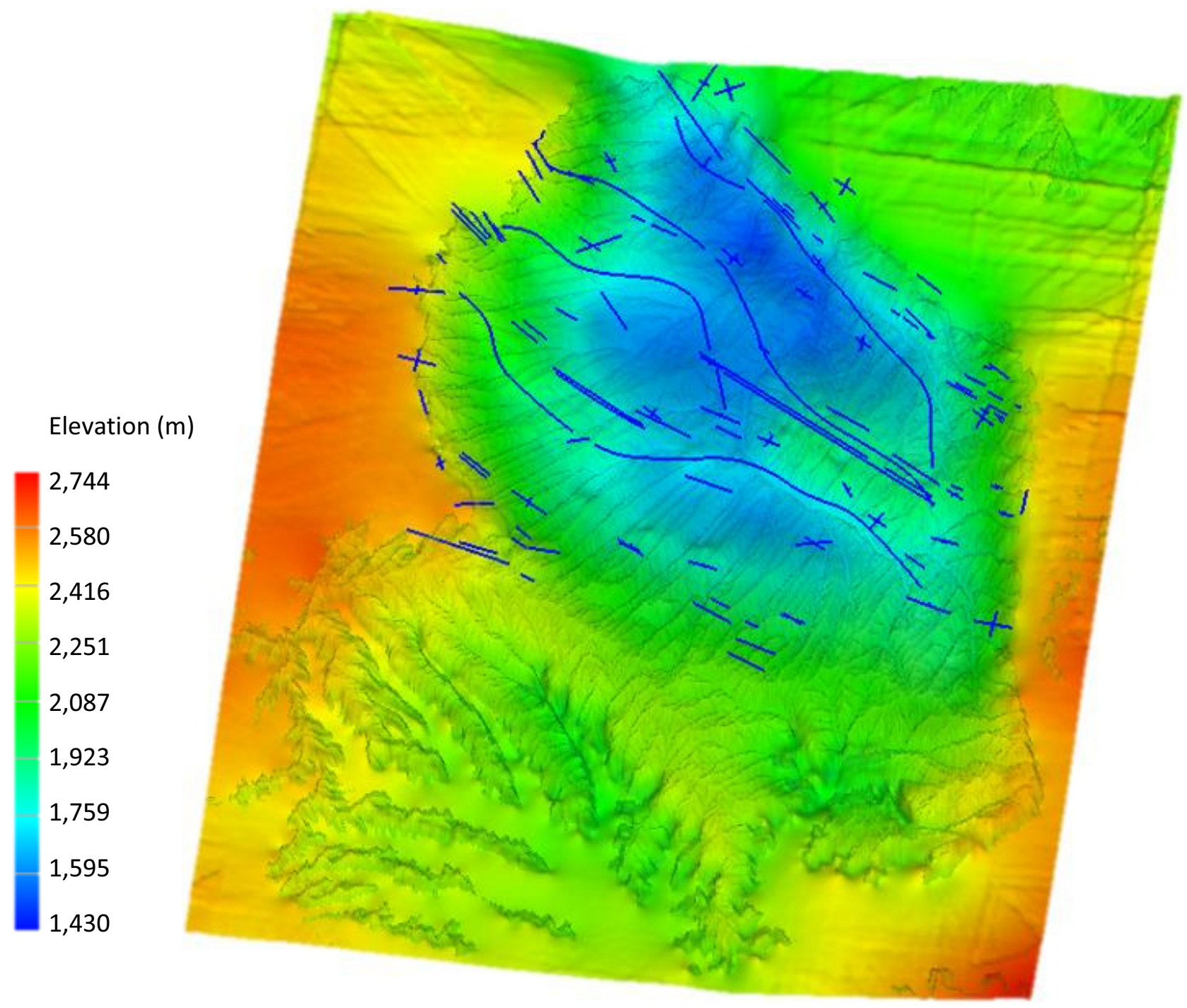



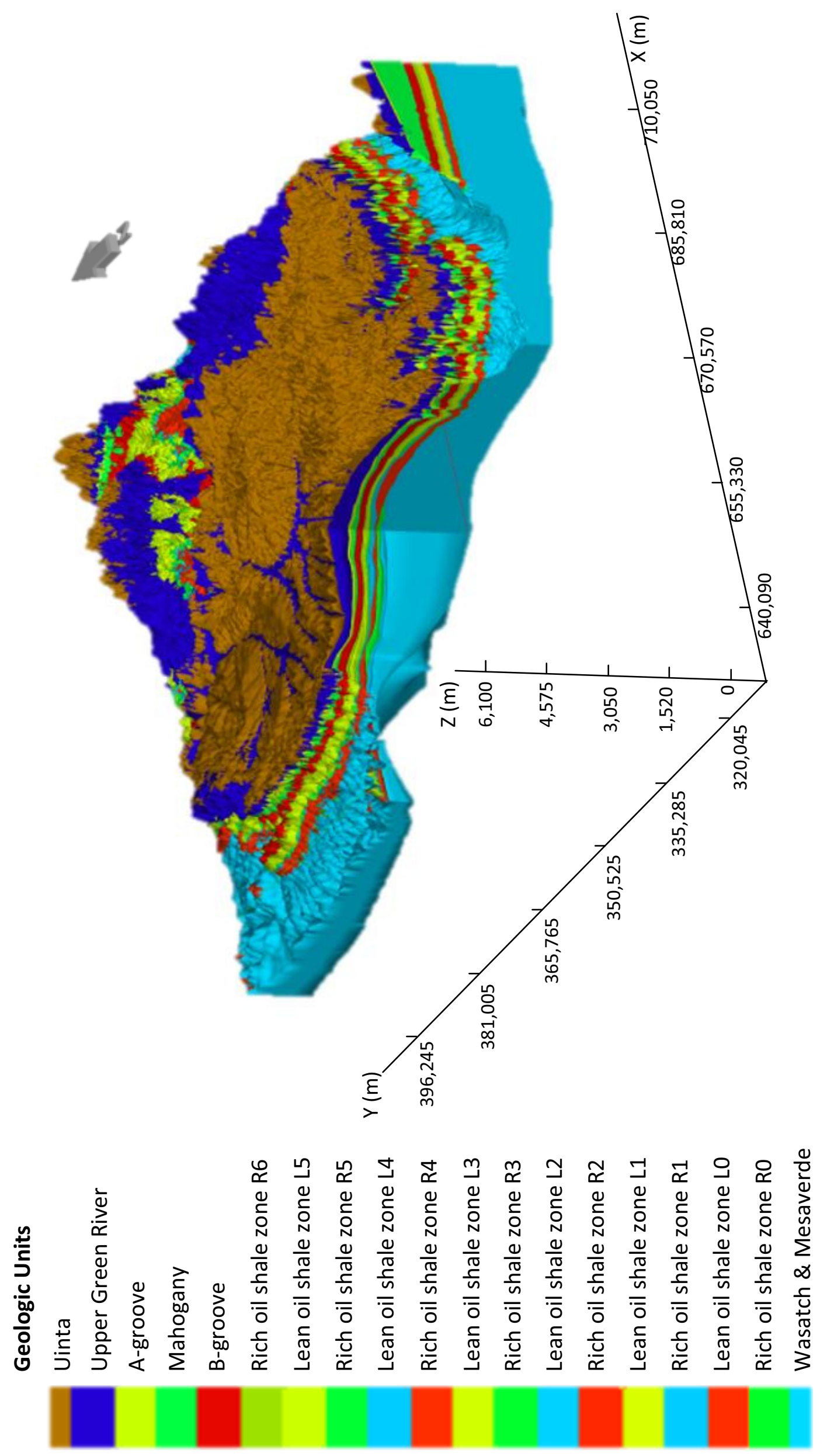


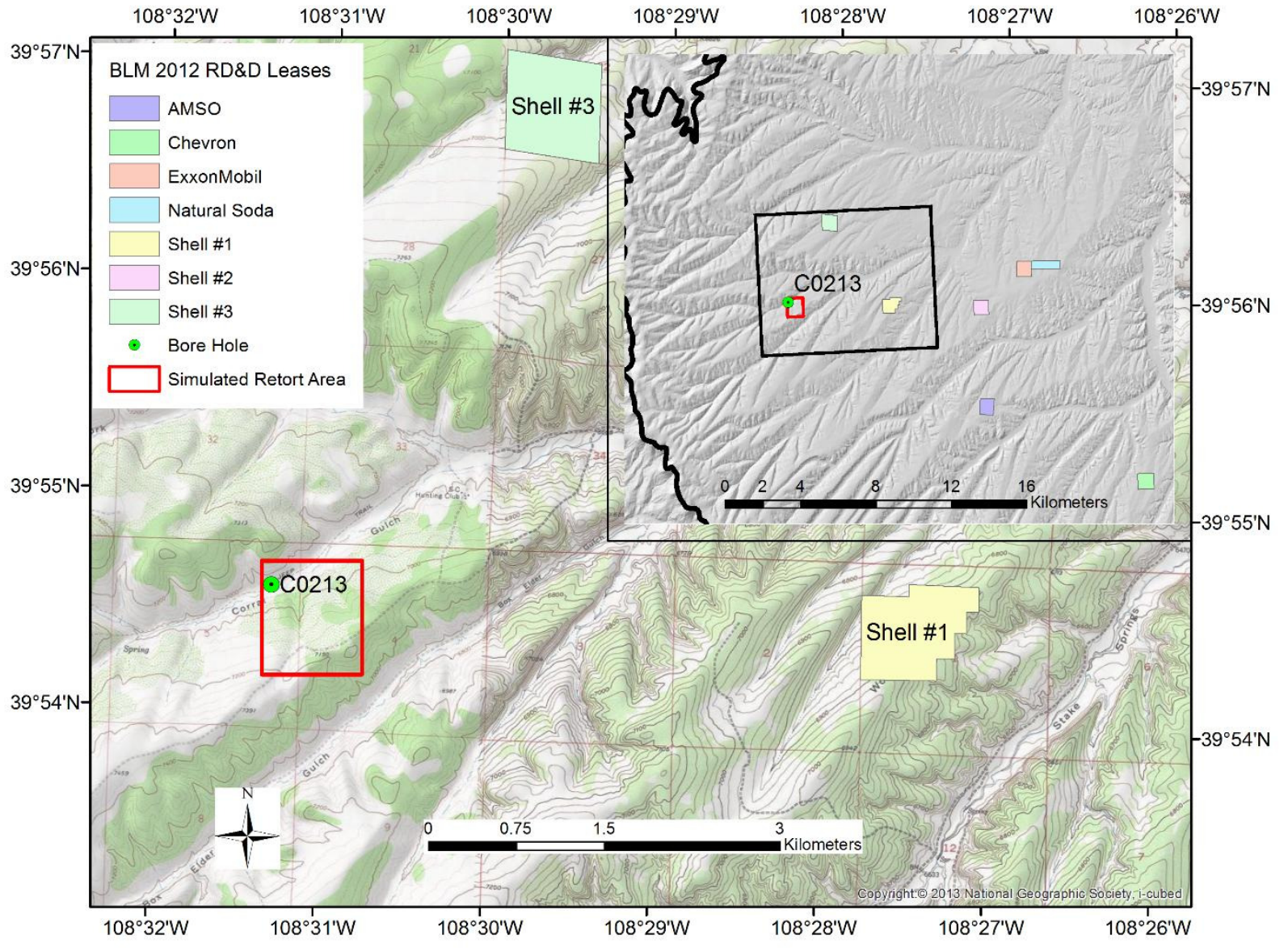



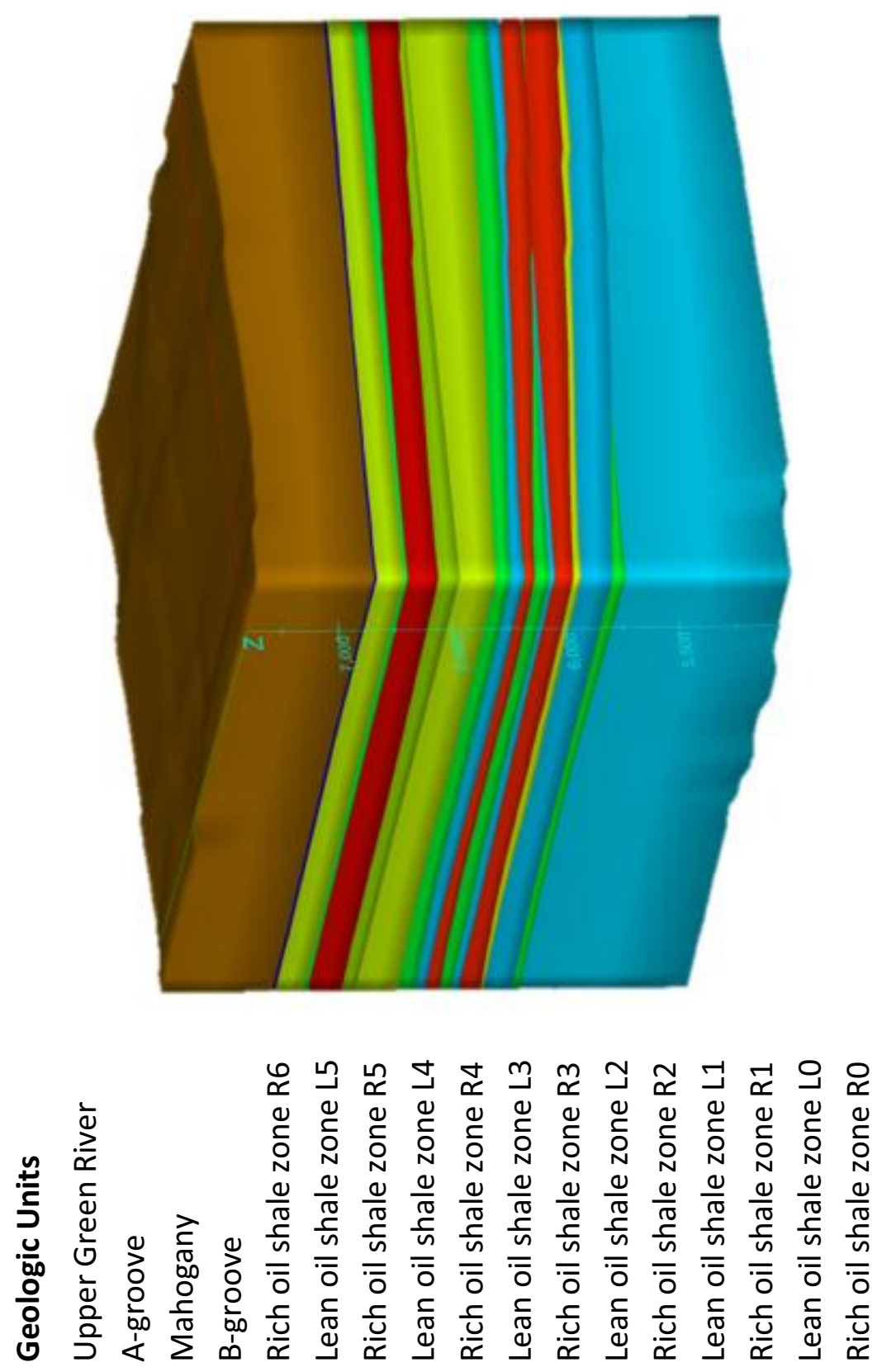


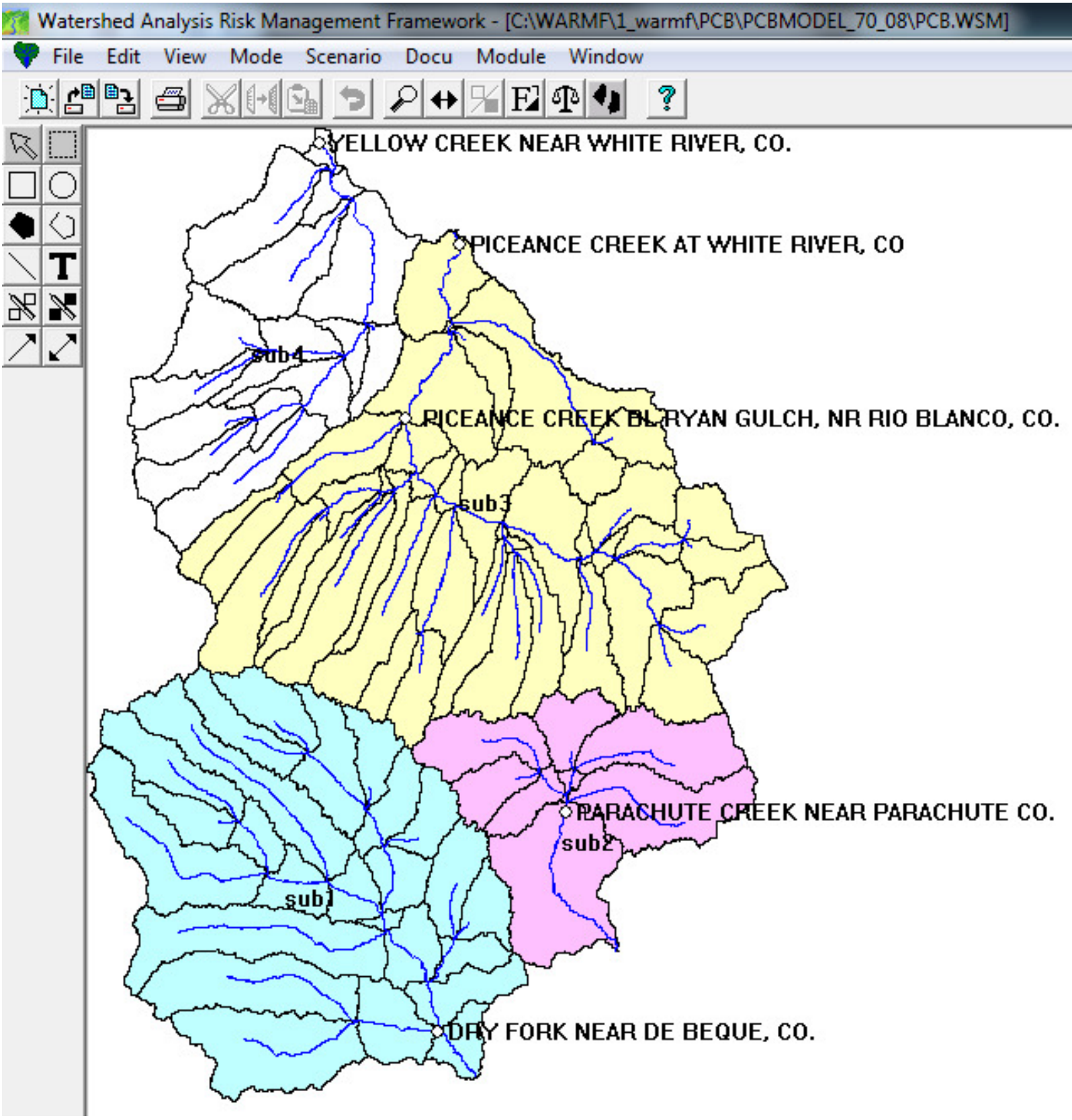

